\title{
Engineering and Technical Support of Territories for Implementation of Renovation Projects of the Housing Stock
}

\author{
Oleg Korol* and Anna Dudina \\ Moscow State University of Civil Engineering, Yaroslavskoe shosse 26, Moscow, 129337, Russia
}

\begin{abstract}
This scientific article researches features of preparations for the construction of renovation projects areas on the example of the city of Moscow. The purpose of the article is to examine and study features of preparations for the construction of renovation projects areas, these feature's being one of the factors determining energy efficiency activities application at a construction site. Statistical data compilation method, regulatory documents examination method and method of review, comparison and consolidation of information are used in this paper. In the context of the research engineering equipment provision of housing stock renovation sites is analysed and renovation areas classification based on water, heat and power supply system's provision is provided. As a result of the analysis of five renovation areas, a number of specific features of renovation areas engineering equipment provision are identified. For the most part Moscow renovation areas are divided into two forms: energydeficient (EP) which lack reserve margins of fuel and power resources; energy-excessive (ER) which have an excess supply of fuel and power resources. Energy-balanced areas (EB) are considered to be of the highest possible level of renovation areas development.
\end{abstract}

\section{Introduction}

The problem energy preservation during renovation of built-up areas is complex and covers all stages of the renovation areas development. The existing five-storey apartment blocks are interconnected with the existing system engineering networks and communication which form fuel and energy supply of both the renovation areas and the city of Moscow as a whole. When implementing the renovation process which is a transition from the existing five-story apartment blocks to modern multi-storey apartment blocks there is a problem of fuel and energy balance in all stages of the process, namely: maintenance of the «old» fivestory apartment blocks, demolition and new construction, maintenance of modern high-rise apartment blocks. In this regard, the construction process is specific in nature, which should imply the rationing of fuel and energy resources (FER). [1], which allows to regulate energy preservation in the construction industry, increase the efficiency of FER usage and transfer energy consumption in construction organizations to the regulatory framework [1].

*Corresponding author: mr.korol.oleg@gmail.com, dudinaanna945@gmail.com 
At the development stage of the construction organization project, the main task is to calculate the required capacity of all types of energy consumers to ensure the connection of the construction site to the city engineering networks or local energy sources and their uninterrupted work for the entire construction period. In this case, as a rule, the consumption of FER is not calculated, and the capacity is determined with a margin [2, 3].

When developing a works performed project on the basis of a feasibility studies, organizational and technological decisions affecting the consumption of fuel and energy resources at the construction site, as well as the results of preparation of the construction site, which provide baseline data to interconnect permanent and temporary engineering communications at the construction site are concretized [2,3].

The problem of energy preservation at a construction site has been under-researched and was examined in various scientific works [2-6], which addressed: general principles and approaches to energy preservation, analysis of various energy consumers at the site, the impact of seasonal and climate impacts on building production, energy preservation at various stages of construction production excluding demolition, and also FER consumption groups were classified, the factors and the degree of their influence on the amount of energy consumption in the construction industry were determined [6]. However, the agenda of these works did not touch upon such specific areas of development as renovation areas, which actualizes scientific research on the issue of energy preservation at the construction site in the renovation process.

\section{Materials and Methods}

To conduct a research in this article the renovation program of the housing stock in the city of Moscow, the technical specifications for the architectural and urban planning of experimental sites for the renovation of the housing stock in Moscow, as well as the principles of the organization of the construction process during the renovation period were used. We used the methods of systematization of engineering data, the study of regulatory documentation, analysis, comparison and synthesis of information. Construction preparations are regulated by the joint venture 48.13330.2011 «SNiP 12-01-2004. Organization of construction» and STO NOSTROY 2.33.14-2011 «Organization of construction production. General provisions» $[7,8]$.

The preparatory period of construction is a «physical» implementation of activities at the construction site, envisaged by the organizational period, which includes: off-site and on-site work (site preparation, site engineering preparation, mobile (inventory) complexes construction [8]).

At the preparatory stage of the construction industry it is important to determine the actual location of the places and conditions for connecting temporary engineering communications to permanent networks to provide the construction site with fuel and energy resources such as electricity, water, heat and steam.

A specific feature of the implementation of renovation projects in the city of Moscow in terms of construction site preparations and energy efficient component of the construction process is consideration of the provision of the construction site with engineering networks and the release of the renovated area, namely the demolition and dismantling of the existing five-story building.

For fuel and energy support of power and technological consumers at the construction site, outdoor and indoor lighting of construction objects, utility-auxiliary buildings, areas of execution of construction and engineering work, permanent and temporary networks are used, that is, the rationing of FER depends on rational organizations of temporary construction infrastructure: temporary water supply and temporary energy supply for construction, which are temporary at building sites. 
A distinctive feature of the renovated area for demolition and new construction is the existing and functioning fuel and energy support for the apartment block, that is, the existence of trunk and engineering networks and utilities (water, heat, gas and electricity) that form the initial parameters of the engineering conditions of the construction site. The use of permanent engineering networks in conjunction with temporary ones is established by the following parameters:

- energy loads calculation;

- energy sources choice;

- identification of objects of service of the first category (objects requiring backup power that is water decrease, electric heating, boiler rooms, fire pumps, etc.), located in the territory;

- working scheme of electricity supply, heat supply, gas supply and water supply mapping [2, 3].

Table 1.Technical and economic indicators of the renovation area.

\begin{tabular}{|c|c|c|c|c|c|}
\hline $\begin{array}{l}\text { Technical } \\
\text { and } \\
\text { economic } \\
\text { indicators }\end{array}$ & $\begin{array}{l}\text { Golovinsky } \\
\text { District }\end{array}$ & $\begin{array}{c}\text { Prospect } \\
\text { Vernadsky } \\
\text { District }\end{array}$ & $\begin{array}{c}\text { Kuzminki } \\
\text { District }\end{array}$ & $\begin{array}{c}\text { Khoroshevo- } \\
\text { Mnevniki } \\
\text { District }\end{array}$ & $\begin{array}{c}\text { Tsaritsyno } \\
\text { District }\end{array}$ \\
\hline Plot area, ha & 133 & 126,4 & 109,65 & 125,9 & 106,81 \\
\hline $\begin{array}{c}\text { Saved housing } \\
\text { area, sqm }\end{array}$ & 522000 & 702580 & 355860 & 713750 & 321320 \\
\hline $\begin{array}{l}\text { Existing housing } \\
\text { density, sqm/ha }\end{array}$ & 7600 & 10400 & 9300 & 8400 & 7800 \\
\hline $\begin{array}{c}\text { Population, } \\
\text { people } \\
1-5 \text { fl. housing } \\
6-12 \text { fl. housing } \\
13-16 \text { fl. housing } \\
17+\text { fl. housing }\end{array}$ & $\begin{array}{c}26982 \\
57 \% \\
22 \% \\
16 \% \\
5 \%\end{array}$ & $\begin{array}{c}22129 \\
55 \% \\
13 \% \\
15 \% \\
17 \%\end{array}$ & $\begin{array}{c}28985 \\
64 \% \\
26 \% \\
1 \% \\
9 \%\end{array}$ & $\begin{array}{c}26942 \\
54 \% \\
27 \% \\
8 \% \\
9 \%\end{array}$ & $\begin{array}{c}11190 \\
65 \% \\
32 \% \\
1 \% \\
2 \%\end{array}$ \\
\hline
\end{tabular}

For the analysis of engineering provision of development sites, five areas of Moscow where renovation projects will be implemented in the future were considered: Golovinsky district, Kuzminki district, Vernadsky Prospect district, Khoroshevo-Mnevniki district and Tsaritsyno district (see figure 1).

Security zones of the main engineering networks and communications are established in accordance with: joint venture 42.13330.2011, MGSN 1.01-99, SanPiN 2.1.4.1110-02, Decree of the Government of Moscow of September 17, 1996 No. 788, joint venture 124. 13330.2012 Thermal networks, joint venture 62.13330.2011, as well as experiences of operational services [9-13]. 
a)

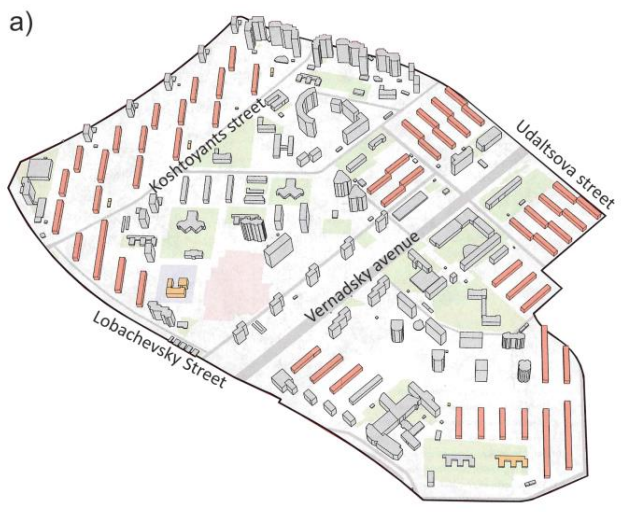

c)

d) Marshal Tukhachevsky street
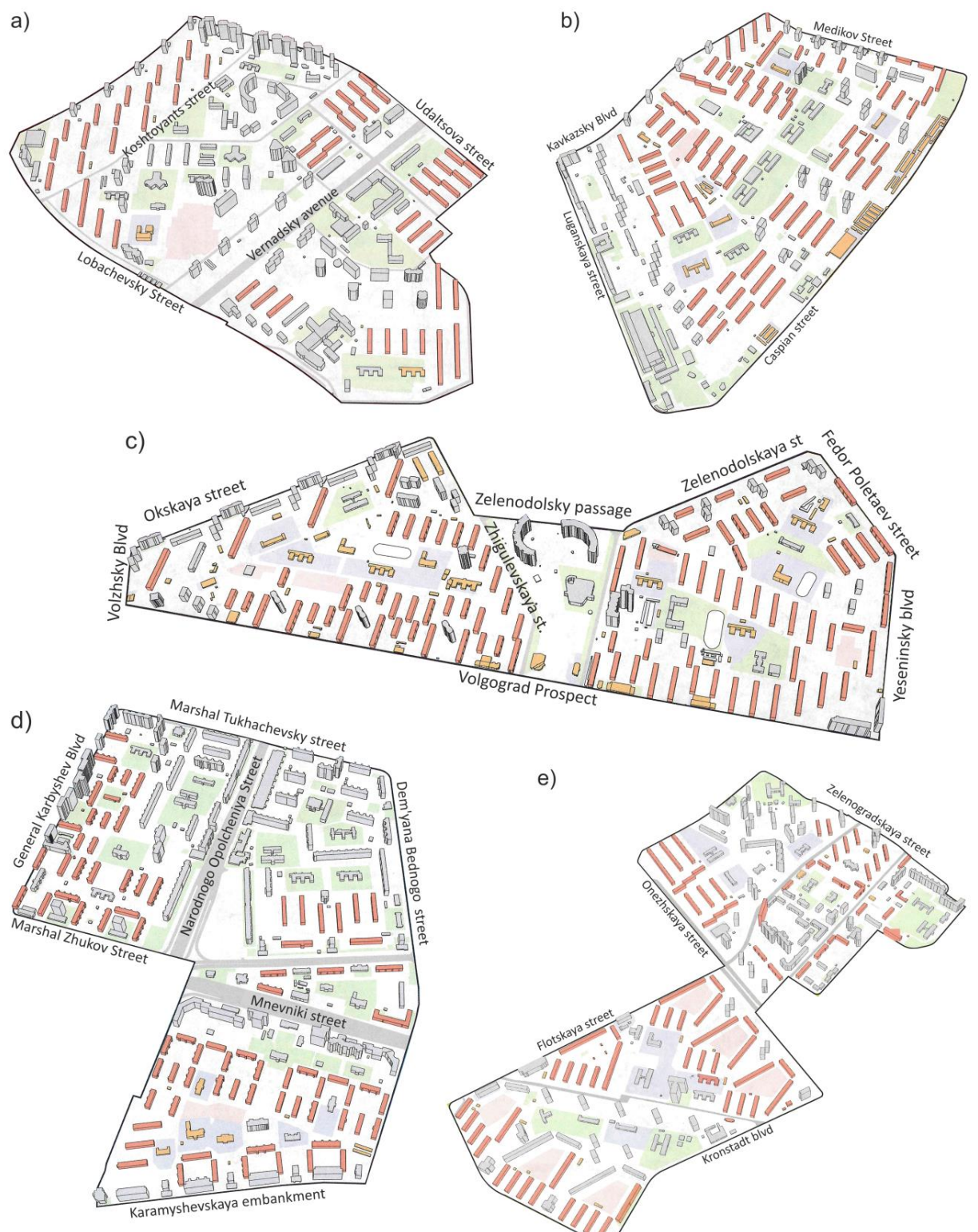

e)

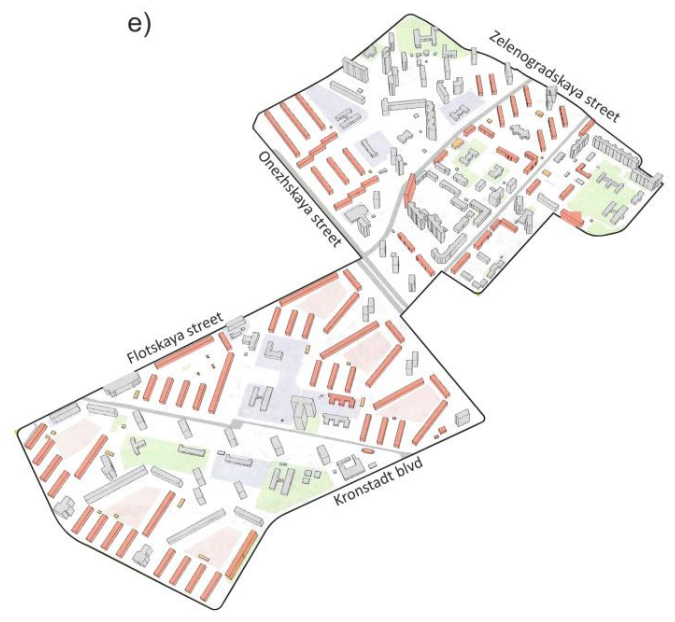

a) Prospect Vernadsky district; b) Tsaritsyno district;

c) Kuzminki district; d) Khoroshevo-Mnevniki district; e) Golovinsky district.

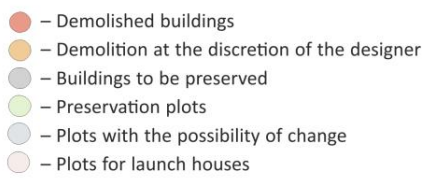

Fig. 1. Renovation projects areas 
Table 2. Summarized engineering equipment supply data for renovation projects development sites.

\begin{tabular}{|c|c|c|c|}
\hline $\begin{array}{c}\text { Construction } \\
\text { areas }\end{array}$ & Water supply & Heating supply & $\begin{array}{l}\text { Electrical power } \\
\text { supply }\end{array}$ \\
\hline $\begin{array}{c}1 . \\
\text { Golovinsky } \\
\text { District }\end{array}$ & $\begin{array}{l}\text { The area is located is within the } \\
\text { area of affect of the Northern } \\
\text { Water Treatment Station (CER). } \\
\text { According to the data of JSC } \\
\text { Mosvodokanal, as of January } 1 \text {, } \\
2005 \text {, the capacity of the CER } \\
\text { amounted to } 1.92 \text { million m } 3 \text { / } \\
\text { day, and there is currently a } \\
\text { water supply reserve for new } \\
\text { consumers. } \\
\text { The power sources of the } \\
\text { territory under consideration are } \\
\text { water conduit CER } d=1200 \\
\text { mm, passing through the intra- } \\
\text { quarter territory and along } \\
\text { Onezhskaya street, water conduit } \\
\text { CER } d=1400 \text { mm and highway } \\
d=900 \text { mm along Flotskaya } \\
\text { street [9]. }\end{array}$ & $\begin{array}{l}\text { The area is located in the } \\
\text { coverage area of CHP } 21 \text {, } \\
\text { which has a capacity } \\
\text { reserve. The heating supply } \\
\text { of the apartment block is } \\
\text { provided by the branches } 2 \mathrm{~d} \\
=900-1000 \mathrm{~mm} \text {, laid along } \\
\text { the Naval street. Consumers } \\
\text { are connected to heat } \\
\text { networks via heat points } \\
\text { (CHP and ITP) [9]. }\end{array}$ & $\begin{array}{l}\text { The electrical } \\
\text { power supply of the } \\
\text { existing apartment } \\
\text { block is carried out } \\
\text { at a voltage of } 6-10 \\
\mathrm{kV} \text { from electrical } \\
\text { substations } \\
220 / 110 / 10 / 6 \quad \mathrm{kV} \\
\text { «Novobratsevo», } \\
110 / 10 / 6 \text { kV } \\
\text { «Leningradskaya» } \\
\text { and «Koptevo» } \\
110 / 10 \text { / 6kV. SS } \\
\text { «Leningradskaya» } \\
\text { has a limited } \\
\text { technological } \\
\text { connection capacity } \\
\text { reserve [9]. }\end{array}$ \\
\hline $\begin{array}{c}\text { 2. Prospect } \\
\text { Vernadsky } \\
\text { District }\end{array}$ & $\begin{array}{l}\text { The area is located within the } \\
\text { area of affect of the Western } \\
\text { Water Treatment Station (ZSV). } \\
\text { According to the data of } \\
\text { Mosvodokanal JSC, the capacity } \\
\text { of the ZSV is } 1.7 \text { million m3 / } \\
\text { day. There is currently a water } \\
\text { supply reserve for new } \\
\text { consumers. } \\
\text { The source of water supply of the } \\
\text { territory in question is: highway } \\
\mathrm{d}=1200 \text { mm along Vernadsky } \\
\text { Avenue and highway d = } 900 \\
\text { mm along st.Lobachevsky [10]. }\end{array}$ & $\begin{array}{l}\text { The area is located in the } \\
\text { coverage area of CHPP- } 25 \text {, } \\
\text { which has a capacity } \\
\text { reserve } \\
\text {. The heating supply of the } \\
\text { building is carried out from } \\
\text { the heating main } 2 \mathrm{~d}=1200 \\
\mathrm{~mm} \text { laid along } \\
\text { Lobachevsky Street. } \\
\text { Branches from the heating } \\
\text { line } 2 \mathrm{~d}=400 \mathrm{~mm}, 2 \mathrm{~d}=500 \\
\mathrm{~mm} \text { and } 2 \mathrm{~d}=800 \mathrm{~mm} \text { pass } \\
\text { through the territory of } \\
\text { square. 32-33 and } 34-35 \text {. } \\
\text { Consumers are connected to } \\
\text { heat networks using heat } \\
\text { points (CHP and ITP) [10]. }\end{array}$ & 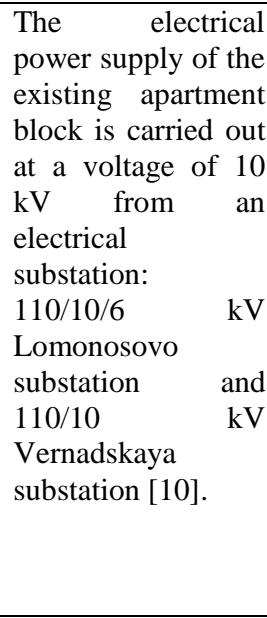 \\
\hline $\begin{array}{l}\text { 3. Kuzminki } \\
\text { District }\end{array}$ & $\begin{array}{l}\text { The area is located within the } \\
\text { area of affect of the Eastern } \\
\text { Water Treatment Station. } \\
\text { According to the data of JSC } \\
\text { Mosvodokanal, the capacity of } \\
\text { the BCA is } 1.4 \text { million } \mathrm{m} 3 \text { / day. } \\
\text { There is a water supply reserve } \\
\text { for new consumers. Water } \\
\text { supply is carried out through } \\
\text { Kuzminsky regulating unit (RU). } \\
\text { Sources of water supply of the } \\
\text { territory in question are: the } \\
\text { water lines VSV } 2 \mathrm{~d}=1400 \mathrm{~mm} \\
\text { along Volzhsky Boulevard, d = } \\
1200 \text { mm along Okskaya Street } \\
\text { and the highway d = 900 mm, }\end{array}$ & $\begin{array}{l}\text { The area is located in the } \\
\text { coverage area of CHP-22, } \\
\text { which has a capacity } \\
\text { reserve. The heating supply } \\
\text { of the building is carried out } \\
\text { by branches } 2 \mathrm{~d}=150-700 \\
\mathrm{~mm} \text { from the heating main } \\
2 \mathrm{~d}=1200 \mathrm{~mm} \text { which is } \\
\text { laid along Zhigulevskaya } \\
\text { Street. Consumers are } \\
\text { connected to heat networks } \\
\text { through heat points (CHP } \\
\text { and ITP) [11]. }\end{array}$ & 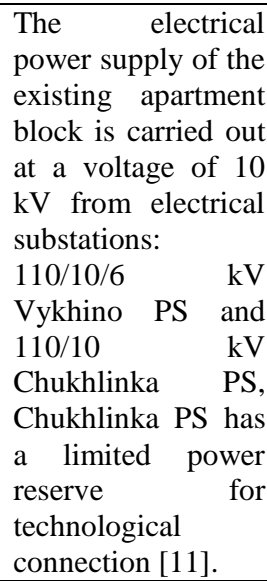 \\
\hline
\end{tabular}




\begin{tabular}{|c|c|c|c|}
\hline & $\begin{array}{l}\text { passing from } \text { Zelenodolskaya } \\
\text { Street [11]. }\end{array}$ & & \\
\hline \begin{tabular}{|c|}
4. \\
Khoroshevo- \\
Mnevniki \\
District
\end{tabular} & $\begin{array}{l}\text { The area is located within the } \\
\text { area of affect of the Rublevskaya } \\
\text { water treatment station (RSV). } \\
\text { RSV capacity is } 1.35 \text { million m3 } \\
\text { / day. According to data from } \\
\text { Mosvodokanal, a water supply } \\
\text { reserve for new consumers is } \\
\text { currently available. } \\
\text { Sources of water supply of the } \\
\text { territory in question are: highway } \\
\mathrm{d}=800 \mathrm{~mm} \text {. along Berzarin } \\
\text { Street, highway d }=600 \mathrm{~mm} \text {. on } \\
\text { the street People's Militia, } \\
\text { highway d }=500-600 \mathrm{~mm} \text {. along } \\
\text { Marshal Zhukov Ave. [12]. }\end{array}$ & $\begin{array}{l}\text { The area is located within } \\
\text { the area of affect of } \\
\text { CHP-16 and CHP-25, } \\
\text { which have a capacity } \\
\text { reserve. The heating supply } \\
\text { of the building is carried out } \\
\text { along branches } 2 \mathrm{~d}=200- \\
500 \mathrm{~mm} \text { from the heating } \\
\text { main } 2 \mathrm{~d}=700 \mathrm{~mm} \text { of } \\
\text { CHPP-16 along the } \\
\text { Mnevniki street and from } \\
\text { the heating main } 2 \mathrm{~d}=1000 \\
\text { mm of CHP-25 along } \\
\text { Marshal Tukhachevsky } \\
\text { street. Consumers are } \\
\text { connected to heat networks } \\
\text { using heat points (CHP and } \\
\text { ITP) [12]. }\end{array}$ & $\begin{array}{l}\text { The electrical } \\
\text { power supply of the } \\
\text { existing apartment } \\
\text { block is carried out } \\
\text { at a voltage of } 10 \\
\mathrm{kV} \text { from the } \\
\text { substation PS: 110- } \\
10 \mathrm{kV} \text { «odynka» } \\
\text { and CHP-16, which } \\
\text { have a reserve } \\
\text { power for } \\
\text { technological } \\
\text { connection [12]. }\end{array}$ \\
\hline $\begin{array}{l}\text { 5. Tsaritsyno } \\
\text { District }\end{array}$ & $\begin{array}{l}\text { The area is located within the } \\
\text { area of affect of the Western } \\
\text { Water Treatment Station (ZSV). } \\
\text { According to the data of } \\
\text { Mosvodokanal JSC, the ZSV } \\
\text { capacity is } 1.7 \text { million m3 / day. } \\
\text { There is a water supply reserve } \\
\text { for new consumers. } \\
\text { The water supply source of the } \\
\text { area in question is the highway d } \\
=900 \mathrm{~mm} \text { at the intersection of } \\
\text { Proletarsky Avenue and } \\
\text { Kavkazsky Boulevard and the } \\
\text { intra-block network d }=600 \mathrm{~mm} \\
\text { [13]. }\end{array}$ & $\begin{array}{l}\text { The area is located in the } \\
\text { zone of the Lenin-Dachnoe } \\
\text { RTS, which has a capacity } \\
\text { reserve. The heating supply } \\
\text { of the building is carried out } \\
\text { by branches } 2 \mathrm{~d}=400-500 \\
\text { mm from the heating main } \\
2 \mathrm{~d}=800 \mathrm{~mm} \text {. Consumers } \\
\text { are connected to heat } \\
\text { networks using heat points } \\
\text { (CHP and ITP) [13]. }\end{array}$ & $\begin{array}{l}\text { The electrical } \\
\text { power supply of the } \\
\text { existing apartment } \\
\text { block is carried out } \\
\text { at a voltage of } 10 \\
\mathrm{kV} \text { from the power } \\
\text { substations: } 110 / 10 \\
\mathrm{kV} \text { Belyaevo } \\
\text { substation and } \\
220 / 110 / 10 \\
\text { Substation } \\
\text { Saburovo. } \\
\text { Substation } \\
\text { Belyaevo has a } \\
\text { limited power } \\
\text { reserve for } \\
\text { technological } \\
\text { connection [13]. }\end{array}$ \\
\hline
\end{tabular}

\section{Results and Discussion}

The analysis we've performed makes it possible to describe the renovation sites engineering equipment supply as follows:

- renovation sites are located within zones of affect of Moscow water treatment plants with capacities that average 1.35-1.92 million m3 / day [9-13], which provides a water supply reserve to the new apartment blocks. Water supply sources are water lines and highways in the intra-quarter territory;

- renovation sites are located within zones of affect of Moscow CHP plant which are provided with a reserve capacity. The power sources are heating mains and TSTP / ITP;

- the renovation sites are located within zones of operation of electrical substations with a voltage of 6-10 kV [9-13], which mainly have a limited technological connection power reserve.

Summarizing the existing engineering and technical conditions of the renovation areas, we can conclude that the permanent (existing) engineering networks will not be able to 
provide the necessary power reserve for the construction and installation works, namely the power supply network, therefore lining of temporary engineering networks and, as a consequence, the development of energy-saving measures at the construction site to preserve the fuel and energy balance of the renovation area are necessary[15-20]

Thus, the renovation areas in the city of Moscow, which are fuel and energy systems of the city, can be divided by water supply provision (WS), heat supply (HS) and electrical power supply (PS) (see table 3) into energy-poor (EP), energy-balanced (EB) and energyredundant (ER), where RE is the power reserve index.

Table 3. Renovation areas typology on the basis of fuel and energy resources provision

\begin{tabular}{|c|c|c|c|c|}
\hline $\begin{array}{l}\text { S. } \\
\text { No }\end{array}$ & Name & \multicolumn{2}{|c|}{ Characteristics } & Symbol \\
\hline \multirow[t]{4}{*}{1} & \multirow[t]{4}{*}{ Energy-poor $\left(\mathrm{E}_{\mathrm{P}}\right)$} & \multirow{4}{*}{$\begin{array}{l}\text { Lack of } \\
\text { FER } \\
\text { reserves in: }\end{array}$} & $\begin{array}{l}\text { water supply system } \\
\text { (WS) }\end{array}$ & \multirow{4}{*}{$E_{P}=\left\{\begin{array}{c}f\left(W S, H S, P T, R_{E}\right) \\
R_{E}<0\end{array}\right.$} \\
\hline & & & $\begin{array}{l}\text { heating supply system } \\
\text { (HS) }\end{array}$ & \\
\hline & & & $\begin{array}{l}\text { electrical power supply } \\
\text { system (PS) }\end{array}$ & \\
\hline & & & $\begin{array}{l}\text { a combination of two or } \\
\text { more engineering } \\
\text { equipment supply } \\
\text { systems }\end{array}$ & \\
\hline 2 & $\begin{array}{l}\text { Energy-balance } \\
\left(E_{B}\right)\end{array}$ & \multicolumn{2}{|c|}{$\begin{array}{l}\text { FER balance for all engineering } \\
\text { equipment supply systems at a } \\
\text { construction site }\end{array}$} & $E_{B}=\left\{\begin{array}{c}f\left(W S, H S, P T, R_{E}\right) \\
R_{E}=R\end{array}\right.$ \\
\hline \multirow[t]{4}{*}{3} & \multirow[t]{4}{*}{$\begin{array}{l}\text { Energy-redundant } \\
\left(\mathrm{E}_{\mathrm{R}}\right)\end{array}$} & \multirow{4}{*}{$\begin{array}{c}\text { FER } \\
\text { reserves } \\
\text { (excess) } \\
\text { availability } \\
\text { in: }\end{array}$} & $\begin{array}{l}\text { water supply system } \\
\text { (WS) }\end{array}$ & \multirow{4}{*}{$E_{R}=\left\{\begin{array}{c}f\left(W S, H S, P T, R_{E}\right) \\
R_{E}>0\end{array}\right.$} \\
\hline & & & $\begin{array}{l}\text { heating supply system } \\
\text { (HS) }\end{array}$ & \\
\hline & & & $\begin{array}{l}\text { electrical power supply } \\
\text { system (PS) }\end{array}$ & \\
\hline & & & $\begin{array}{l}\text { a combination of two or } \\
\text { more engineering } \\
\text { equipment supply } \\
\text { systems }\end{array}$ & \\
\hline
\end{tabular}

\section{Conclusions}

The analysis of five renovation sites revealed a number of distinguishing features of engineering areas supply provision. For the most part Moscow renovation areas are divided into two forms: energy-deficient (EP), which lack reserve margins of fuel and power resources; energy-excessive (ER) which have an excess supply of fuel and power resources. Energy-balanced areas (EB) are considered to be of the highest possible level of renovation areas development. There renovation area fuel and energy balance is maintained at the stage of construction and installation works due to organizational and technological solutions aimed at energy preservation of energy resources within the construction site.

This work was financially supported by Ministry of Science and Higher Education of the Russian Federation (\#NSh-3492.2018.8).

\section{References}

1. Lozovsky A.A, Zemlyakov G.V. Calculation of individual technological norms of 
consumption of fuel and energy resources in the construction industry. Science and Technology. 2011. No. 6. [Electronic resource] URL: https://cyberleninka.ru/article/n/raschet-individualnyh-tehnologicheskih-norm-rashodatoplivno-energeticheskih-resursov-v-stroitelnom-proizvodstve (access date: 11.02.2019).

2. Korol O.A. The main approaches and principles for the formation of a methodology for assessing the effectiveness of energy-saving measures in the construction industry. Scientific Review. 2015 No. 12 pp 393-396.

3. Grabovy K.P., Korol O.A. Analysis of energy consumption at the construction site and reserves of their reduction. Natural and technical sciences. 2014 No. 11-12 (78) pp 399401.

4. Korol O.A Classification and ranking of energy consumption to meet the requirements of energy minimization of modern construction production. Proceedings of the Eighteenth International Interuniversity Scientific and Practical Conference of Students, Master Students, Postgraduates and Young Scientists «CONSTRUCTION - FORMING ENVIRONMENTAL ENVIRONMENT» 2015 pp 970-973.

5. Korol O.A. Analysis of the impact of the number of construction workers on the energy consumption of a domestic town in the conditions of construction production. Natural and Technical Sciences 2015 p 594-596.

6. Lozovsky A.A., Zemlyakov G.V.Rationing of the consumption of fuel and energy resources in the construction industry. Building science and technology. - 2011. - №5 pp 12-17.

7. Set of rules: SP 48.13330.2011 «SNiP 12-01-2004. Organization of construction» Updated edition of SNiP 12-01-2004 (approved by order of the Ministry of Regional Development of the Russian Federation of December 27, 2010 No. 781) [Electronic resource] URL: http://docs.cntd.ru/document/1200084098 (access date: 11.02.2019).

8. Standard of the national association of builders: STO NOSTROY 2.33.14-2011 «Organization of construction production. General Provisions» (approved and put into effect by the Decision of the Council of the National Association of Builders, protocol of December 5, 2011 No. 22) [Electronic resource] URL: http://docs.cntd.ru/document/1200093126 (access date: 11.02.2019).

9. Terms of Reference for the architectural and urban planning management of experimental sites for the renovation of housing in Moscow. District Golovinsky [Electronic resource] URL: http://archsovet.msk.ru/competitions/renovaciya-zhilyhkvartalov-pyatietazhek (access date: 11.02.2019).

10. Terms of Reference for the architectural and urban planning management of experimental sites for the renovation of housing in Moscow. District Vernadsky Avenue [Electronic resource] URL: http://archsovet.msk.ru/competitions/renovaciya-zhilyhkvartalov-pyatietazhek (access date: 11.02.2019).

11. Terms of Reference for the architectural and urban planning management of experimental sites for the renovation of housing in Moscow. District Kuzminki [Electronic resource] URL: http://archsovet.msk.ru/competitions/renovaciya-zhilyhkvartalov-pyatietazhek (access date: 11.02.2019).

12. Terms of Reference for the architectural and urban planning management of experimental sites for the renovation of housing in Moscow. District KhoroshevoMnevniki [Electronic resource] URL: http://archsovet.msk.ru/competitions/renovaciyazhilyh-kvartalov-pyatietazhek (access date: 11.02.2019).

13. Terms of Reference for the architectural and urban planning management of experimental sites for the renovation of housing in Moscow. District Tsaritsyno [Electronic resource] URL: http://archsovet.msk.ru/competitions/renovaciya-zhilyhkvartalov-pyatietazhek (access date: 11.02.2019). 
14. On the Housing Renovation Program in Moscow (as amended on November 8, 2017): Decree of the Government of Moscow of August 1, 2017 No. 497-PP [Electronic resource] URL: http://docs.cntd.ru/document/ 456082244 (access date: 11.02.2019).

15. Borkovskaya V.G. The concept of innovation for sustainable development in the construction business and education. Applied Mechanics and Materials. (Volumes 475476). Chapter 15: Engineering Management. December 2013. Pages 1703-1706. DOI: 10.4028/www.scientific.net/AMM.475-476.1703

16. Borkovskaya V.G. Project Management Risks in the Sphere of Housing and Communal Services. Journal MATEC Web of Conferences, Volume 251, 06025 (2018). DOI: https://doi.org/10.1051/matecconf/201825106025

17. Borkovskaya V, Passmore D. Application of Failure Mode and Effects Analysis in Ecology in Russia. MATEC Web of Conf., 193 (2018) 05027. DOI: https://doi.org/10.1051/matecconf/201819305026

18. Borkovskaya V.G., Degaev E., Burkova I. Environmental economic model of risk management and costs in the framework of the quality management system. MATEC Web of Conf., 193 (2018) 05027. DOI: https://doi.org/10.1051/matecconf/201819305027.

19. Korol O., Shushunova N., Lopatkin D., Zanin A., Shushunova T. Application of Hightech Solutions in Ecodevelopment. Journal MATEC Web of Conferences, Volume 251, 06025 (2018). DOI: https://doi.org/10.1051/matecconf/201825106002.

20. Korol E.A., Gaydysheva Y., Passmore D. Integration of organizational-technological and social aspects in the realization of the program of renovation of residential development. Journal MATEC Web of Conferences, Volume 251, 06025 (2018). DOI: https://doi.org/10.1051/matecconf/201825106025. 